\title{
REVISION OF THE BECKWITH AND BEAR RIVER FORMATIONS OF SOUTHEASTERN IDAHO.
}

\author{
By G. R. Mansfield and P. V. Roundy.
}

\section{INTRODUCTION AND SUMMARY.}

In the detailed geologic mapping of the Wayan and Montpelier quadrangles, in southeastern Idaho and adjacent territory, it has been found necessary to apply new names to strata hitherto referred to the Beckwith and Bear River formations or to portions of the Laramie as mapped by the Hayden Survey. The two quadrangles are contiguous, and the Montpelier quadrangle lies south of the Wayan. They occupy the corner of the State and include a very narrow strip in northeastern Utah and a somewhat broader strip in western Wyoming. They lie between parallels $42^{\circ}$ and $43^{\circ}$ $\mathrm{N}$. and meridians $111^{\circ}$ and $111^{\circ} 30^{\prime} \mathrm{W}$. The Wayan 30-minute quadrangle, the topographic map of which has not yet been published, consists of four 15-minute quadrangles, the Freedom, Lanes Creek, Crow Creek, and Slug Creek. Topographic maps of these areas are now available.

The formations to be discussed extend from the northeastern part of the Montpelier quadrangle northward through the eastern part of the Wayan quadrangle and thence northward an undetermined distance, possibly including a considerable part of the Caribou Range. They include about 17,000 feet of strata, unless there are unrecognized repetitions by folding or faulting.

Two large groups of beds are recognizable in the field. At first, in accordance with earlier interpretations, these groups were assigned respectively to the Beckwith formation, of Cretaceous and Jurassic age, and the Bear River formation, of Upper Cretaceous age. On the maps of the Hayden Survey both are included in the Laramie. There is, however, considerable lack of agreement both lithologically and faunally between these formations as exposed in the district under discussion and as $30830^{\circ}-17-6$ exposed in the region of their type localities. Descriptions of the Beckwith formation in the areas where it has been studied show considerable variety in lithologic character. The fossil content is meager, and there is uncertainty about the upper limit of the formation.

The Bear River formation has long been known and has been studied by many geologists. It has a distinctive fauna and nearly as distinctive a lithology. The lack of agreement between the beds in the Wayan quadrangle heretofore called Bear River and the typical Bear River is so marked as to raise the question whether any of these beds can properly be assigned to that formation. The beds in the Wayan quadrangle resemble somewhat the Kootenai of Montana and Canada and may in part represent that formation. They may furnish a connecting link between the Kootenai and the Bear River.

The strata in this area that were formerly called the Bear River are here assigned to the Wayan formation, of Cretaceous, possibly Lower Cretaceous age, and the so-called Beckwith is divided into seven formations, of which the lower two are marine formations of Jurassic age, and the remaining five are nonmarine formations assigned to the Gannett group, of Cretaceous (?) age. This paper gives a statement of the stratigraphic problems involved and a description of the formations. The writers are indebted to Mr. T. W. Stanton for examination of the fossils and for helpful suggestions.

\section{GENERAL STRATIGRAPHY OF THE AREA.}

The stratigraphic sequence in southeastern Idaho is remarkably full, all the great Paleozoic and later systems being represented. The Paleozoic formations are identical in name and number with the corresponding formations of 
northern Utah described by Richardson, ${ }^{1} \mid$ those of the Utah section. The subjoined table except that the Threeforks limestone has not shows the general character of the Mesozoic been recognized. The Idaho formations dif- formations of the region and the relations of fer somewhat in thickness and character from the formations here discussed to the others.

Mesozoic formations in southeastern Idaho.

\begin{tabular}{|c|c|c|c|}
\hline System and series. & Formation. & Character. & $\begin{array}{l}\text { Thickness } \\
\text { (feet). }\end{array}$ \\
\hline Cretaceous (Lower Cretaceous?). & Wayan formation. & $\begin{array}{l}\text { Sandstones, shales, carbonaceous shales, } \\
\text { limestones, some conglomerate ........ }\end{array}$ & 11,800 \\
\hline Unconformity & Gannett group. & 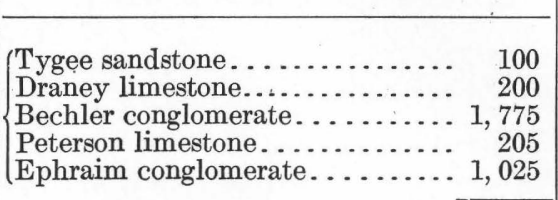 & 3,305 \\
\hline \multirow{3}{*}{ Jurassic. } & Stump sandstone. & 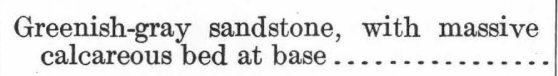 & $200-600$ \\
\hline & Preuss sandstone. & Red sandstones and shales ............. & 1,300 \\
\hline & Twin Creek limestone. & 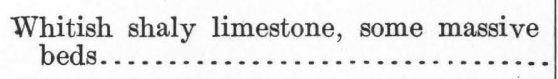 & $3,500 \pm$ \\
\hline Jurassic or Triassic. & Nugget sandstone. & $\begin{array}{l}\text { Subdivided into four members: Red } \\
\text { sandstone, with heavy grit at base, suc- } \\
\text { ceeded by cherty limestone and red } \\
\text { shale. Raymond Canyon section..... }\end{array}$ & 1,900 \\
\hline \multirow{3}{*}{ Triassic (Lower Triassic). } & Ankareh formation. & 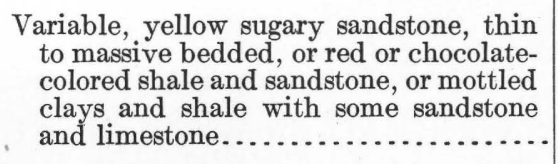 & $750 \pm$ \\
\hline & Thaynes limestone. & 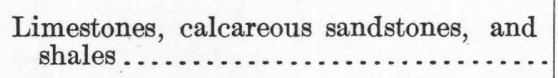 & $2,000 \pm$ \\
\hline & Woodside shale. & 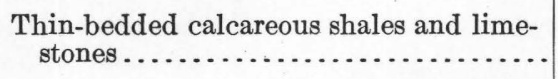 & 1,500 \\
\hline
\end{tabular}

THE BECKWITH PROBLEM.

The Beckwith formation has been identified at several localities in western Wyoming and adjacent parts of Idaho by a number of geologists, but present knowledge of the formation

1 Richardson, G. B., The Paleozoic section in northern Utah: Am. Jour. Sci., 4th ser., vol. 36, pp. 406-416, 1913. is largely derived from the three principal published descriptions, which represent more or less separated districts and contain differences sufficient to warrant a brief discussion. Their main features are set forth in the following table, which includes also the correlations given in the present report: 
Tentative correlation of the Beckwith and Bear River formations in southeastern Idaho and southwestern Wyoming.

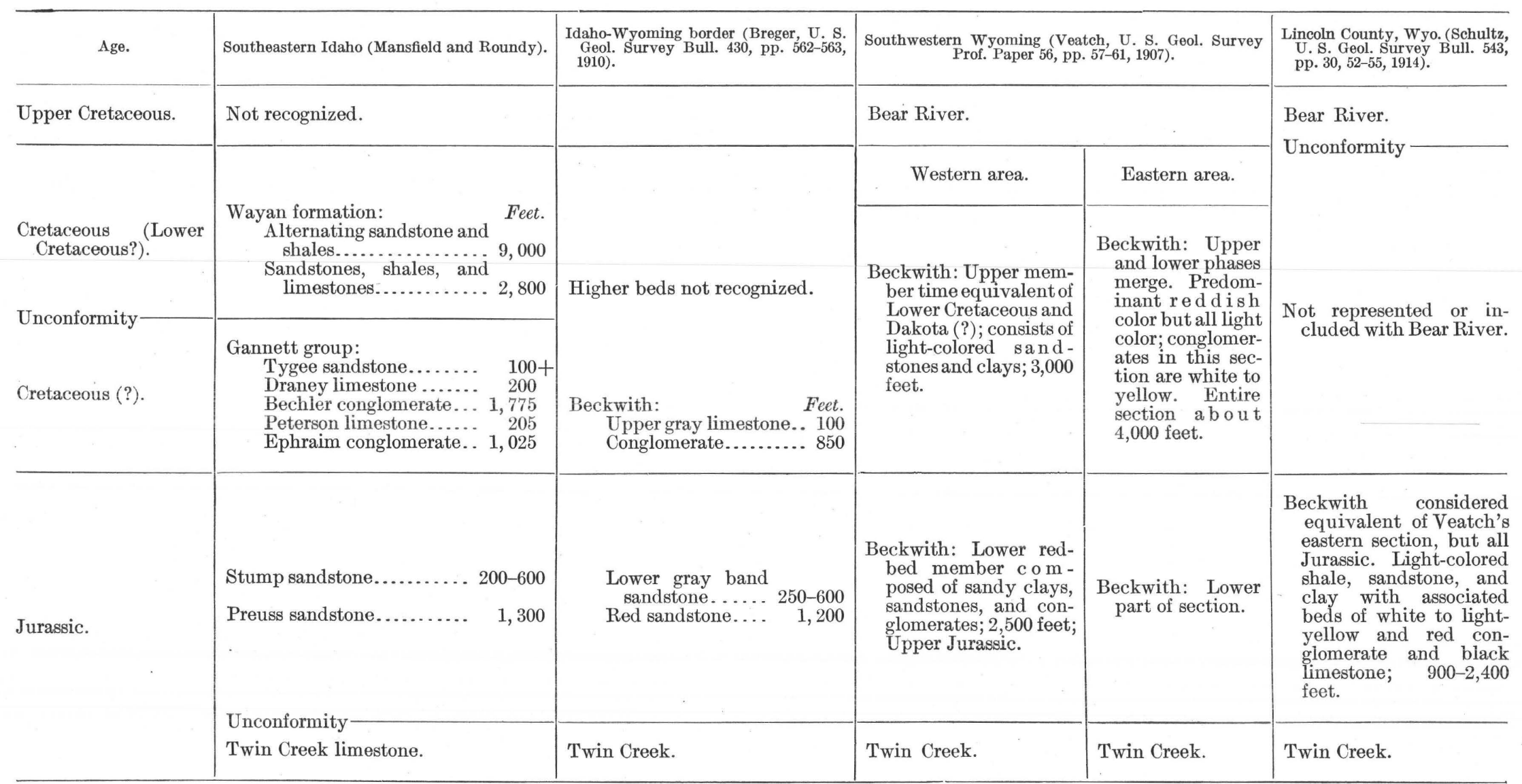


Veatch, ${ }^{1}$ who defines and describes the formation, divides it into two unnamed members"a lower red-bed member composed of interbedded sandy clays, sandstones, and conglomerates 2,500 feet thick, and an upper member composed of rather light-colored interbedded sandstones and clays with a thickness of 3,000 feet or more." In the eastern exposures within his district these two phases merge. "Just west of Hilliard these beds, while having a predominant reddish cast, are all light in color. The conglomerates, which near Beckwith are deep red, are here white to yellow." Veatch appears not to have found fossils in the Beckwith, but he refers to this formation collections of marine Jurassic fossils previously made by Stanton at two localities, one of which was outside of the district described. On the evidence of these fossils he refers the lower part of the Beckwith to the Jurassic; the remainder, he thinks, "contains time equivalents of the Lower Cretaceous and Dakota."

Breger ${ }^{2}$ gives the following account of the Beckwith formation in the Crow Creek region, Idaho, which is included in the Montpelier and Wayan quadrangles:

This formation consists of red sandstone and conglomerates with two conspicuous gray bands. The lower gray band is a dark greenish-gray calcareous sandstone 250 to 600 feet thick and occurs 1,200 feet above the base of the formation. The lower 1,200 feet consists of red sandstones and shales, apparently without conglomerates. The conglomerates seem to be confined *** to the interval above the lower gray band, constituting most of the rocks for a thickness of 850 feet. They are succeeded by the second or upper gray band, a massive limestone, more or less marly and light blue-gray in color. This rock attains a thickness of 100 feet in Stump Canyon and northward, where it forms a resistant ledge that may easily be traced by its light color.

Breger makes no mention of fossils in the formation.

Schultz ${ }^{3}$ describes the formation as it occurs in Lincoln County, Wyo., south of Snake River and east of the Salt River Range and the Absaroka Ridge. There it represents the

direct northward extension of the Beckwith formation of the eastern belt of Uinta County [Veatch's area], where the conglomerate phase merges with the upper sandstone and shale. * * * The beds are composed of light-colored

1 Veatch, A. C., Geography and geology of a portion of southwestern Wyoming: U. S. Geol. Survey Prof. Paper 56, pp. 57-58, 1907.

2 Breger, C. L., The salt resources of the Idaho-Wyoming border, with notes on the geology: U. S. Geol. Survey Bull. 430, pp. 562-563, 1910.

3 Schultz, A. R., Geology and geography of a portion of Lincoln County, Wyo.: U. S. Geol. Survey Bull. 543, pp. 30, 53, 54, 1914. shale, sandstone, and clay. The sandstone is usually light yellow, pink, or white, and the clay varies from yellow or light pinkish red to dark purple. With the sandstone, shale, and clay are associated beds of white to light yellow and red conglomerate and black limestone. In places * * * conglomerate beds constitute an important part of the formation.

Fossils are not numerous, but Schultz obtained collections from four localities. These were examined by Stanton, who referred three of the collections to the Jurassic and stated that the fourth was not sufficient for age determination but suggested Jurassic. According to Schultz two of the lots "come from the top of the Beckwith and indicate that it is Upper Jurassic." The thickness of the formation in the region ranges from 900 to 2,400 feet.

Lithologically the descriptions given by Veatch and Schultz agree fairly well, except that in Schultz's area the red conglomeratic phase seems not to be well developed. In both areas sandstones and clays predominate in the formation. Conglomerates appear to be of relatively minor importance. Veatch makes no mention of limestone, but Schultz refers to beds of black limestone. Breger, on the other hand, does not mention clays, but emphasizes two gray bands, one of sandstone and the other of limestone, with an intermediate massive conglomerate. He also notes the presence of a thick band of red sandstones and shales below the lower gray band. Thus he divides the formation into a series of bands which, he says, "maintain these characters throughout the area covered by the present reconnaissance, * * * a distance of about 35 miles." The formation in the Wyoming region appears to be more variable, and the subdivisions noted by Veatch and Schultz do not appear to continue over considerable areas.

The study of the Wayan and Montpelier quadrangles has given the writers an opportunity to review in some detail Breger's work on the Beckwith and to cover a somewhat larger area than he examined. They have also seen the Beckwith northeast and southeast of Evanston, Wyo., but have not been able to make extended observations there. In the Idaho region they recognized the four bands described by Breger and found three additional higher ones, but in the portions of the Wyoming Beckwith seen they did not observe any similar arrangement. Perhaps the most striking differences noted in the two regions were the 
greater abundance of conglomerates and limestones and more intense red color in the Idaho area contrasted with the predominance of sandstones and clays of lighter colors in the Wyoming area.

Faunally there are several differences to be noted. Veatch refers the lower part of the Beckwith to the Jurassic, but there is an element of doubt in this reference, because of the possibility that the fossils collected earlier by Stanton may have come from unrecognized in-faulted Twin Creek beds, although Veatch does not regard this as probable. The upper beds he considers Cretaceous. Schultz found Jurassic fossils in the top of the Beckwith in his area, and yet he regards the formation there as the direct northward continuation of Veatch's combined section. In the Idaho area the writers found marine Jurassic fossils just at the base of Breger's lower gray band, but the limestone beds higher in the section contain a fresh-water fauna that is thought by Stanton to be later that Jurassic, having affinities with those of the Kootenai and Bear River formations. Nothing comparable to this fresh-water fauna has yet been reported from the other Beckwith areas.

Schultz, ${ }^{1}$ from work in Wyoming and Utah, the results of which have not yet been published, has come to look upon the Beckwith as a group rather than a single formation. It is thus seen that the term Beckwith as now used has no very definite meaning, that it is applied to widely varying beds, some of which may not be closely related, and that it probably covers beds belonging to two great systems.

The writers have found it practicable to subdivide the beds hitherto called Beckwith in the Wayan and Montpelier quadrangles into seven formations, two Jurassic and five Cretaceous (?). In view of the above discussion it seems unwise to retain the name Beckwith for any of these formations and new names are therefore assigned. Detailed descriptions of the formations are given on pages $82-83$.

\section{THE BEAR RIVER PROBLEM.}

The Bear River formation early attracted attention because of its numerous and wellpreserved fossils. It was named by Hayden ${ }^{2}$

\footnotetext{
1 Personal communication.

2 Hayden, F. V., U. S. Geol. Survey Terr. Second Ann. Rept., pp. 91-92, 1873.
}

in 1873 , but its true stratigraphic position was not determined until nearly 20 years later by Stanton. ${ }^{3}$ In 1895 White $^{4}$ gave a full description of it, summarizing the information available at that date. Since then other geologists have contributed additional details. (See table on p. 80.)

Although the stratigraphic position of the Bear River has been determined, its relations to the underlying formations are not everywhere clear. It is probable that in some of the earlier accounts strata now assigned to the Beckwith have been included in the Bear River. The formation has not been recognized outside of the region which extends from Old Bear River City, about 9 miles southeast of Evanston, Wyo., northward through the Wyoming and Salt River ranges into the northeastern part of Idaho. ${ }^{5}$

In the Yellowstone Park and extending northward into Canada there is a thick and extensive nonmarine formation, the Kootenai, of Lower Cretaceous age, between which and the Bear River there are certain affinities, but the relations of the two formations to each other are not known. In Idaho and Wyoming there are great thicknesses of strata which have been assigned to the Bear River but in which none of the characteristic Bear River fossils have been found. Stanton ${ }^{6}$ comments as follows on a collection made by Schultz on the west flank of the Caribou Range about 2 miles east of Herman. Idaho:

In my opinion this fauna is Cretaceous, but on account of the absence of definitely characteristic forms I am unable to determine whether it belongs to the Bear River formation. Similar imperfect fossils have been collected in Montana in rocks that are provisionally referred to the Kootenai formation.

The assignment of these and other doubtful beds to the Bear River seems to have been based partly on lithologic resemblances and partly on the actual occurrence in higher beds of characteristic Bear River fossils, as in parts of Lincoln County, Wyo., ${ }^{7}$ and of Bonneville

3 Stanton, T. W., The stratigraphic position of the Bear River forma. tion: Am. Jour. Sci., 3d ser., vol. 43, pp. 98-115, 1892.

4 White, C. A., The Bear River formation and its characteristic fauna: U. S. Geol. Survey Bull. 128, 1895.

${ }^{5}$ Veatch, A. C., op. cit., p. 60.

${ }^{6}$ Schultz, A. R., and Richards, R. W., A geologic reconnaissance in southeastern Idaho: U. S. Geol.'Survey Bull. 530, p. 275, 1913.

${ }^{7}$ Schultz, A. R., Geology and geography of a portion of Lincoln County, Wyo.: U. S. Geol. Survey Bull. 543, pp. 54-59, 1914. 
and Fremont counties in Idaho, north and northeast of the Wayan quadrangle. ${ }^{1}$

The rocks in typical exposures of the Bear River formation may be described as dark shales with calcareous bands and some soft gray sandstones, which are abundantly fossiliferous. A single section which may be regarded as representative may be quoted from Stanton's section on Stowe Creek, ${ }^{2}$ near the type locality.

Part of Stanton's section on Stowe Creek, Wyo.

5. Bear River formation:

Feet.

Brown sandstone; dip $75^{\circ} \mathrm{E} \ldots \ldots \ldots \ldots \ldots .20$

Soft gray shale....................... 25

Gray sandstone.................... 10

Dark shale......................... 60

Brown sandstone ..................... 10

Dark shale with calcareous bands containing numerous fossils: Pyrgulifera humerosa, Corbula pyriformis, Unio belliplicatus........ 250

Sandstone........................... 10

Dark shales with thin bands of limestone and sandstone and occasional carbonaceous seams; many Bear River fossils ........... 400

Gray sandstone; $\operatorname{dip} 75^{\circ} \mathrm{E} \ldots \ldots \ldots \ldots \ldots .10$

Soft shales........................ 25

Gray sandstone; $\operatorname{dip} 75^{\circ} \mathrm{E} \ldots \ldots \ldots \ldots \ldots 20$

840

In some places the shales are sufficiently carbonaceous to carry thin seams of coal, but the coal is generally too poor to be of economic importance.

At a few localities in the Wayan quadrangle there are dark shales with calcareous bands in supposed Bear River strata, but these are not very fossiliferous, and such fossils as occur are not typical of the Bear River. The strata include two rather prominent sets of limestone beds, with which more or less dark shale is interbedded, and great thicknesses of sandstones and shales, some of which are of an intense red color. Lithologically there is no very close agreement between the rocks of the Wayan quadrangle and the typical Bear River, and faunally the relationship is uncertain.

The Kootenai of Canada and Montana contains some coal beds of economic importance. In the Cascade coal basin of Alberta the formation includes some 2,800 feet of sandstones and shales with many valuable coal seams, there being in one locality as many as 14 beds that

I Unpublished data collected by E. G. Woodruff and A. R. Schultz. 2 Stanton, T. W., The stratigraphic position of the Bear River formation: Am. Jour. Sci., 3d ser., vol. 43, p. 106, 1892. are possibly workable. ${ }^{3}$ In the Philipsburg quadrangle, Mont., ${ }^{4}$ the Kootenai formation includes 1,500 feet of variegated beds, chiefly sandstones and shales with some limestones and conglomerates. The "gastropod limestone"5 in that quadrangle is physically much like the limestones of the supposed Bear River in the Wayan quadrangle. It is described as a pure gray limestone rich in fossils, chiefly freshwater snails. The limestones form distinct beds which are separated by shales and crop out as reefs. On fresh fracture the rock is dark gray; on the weathered surface, pale bluish gray. The texture is coarse and less compact than that of the lower limestone. The rock is crowded with spiral shells which are conspicuous on weathered surfaces. The calcareous shale interbedded with and overlying the gastropod limestone is partly of an olive-green, ocherous-weathering type. It grades into sandstones. The uppermost beds consist of more or less calcareous shale, gray to nearly black on fresh fracture but weathering to bluegray or brown; these beds virtually grade into limestone. The limestones of the supposed Bear River in the Wayan quadrangle occur in the same manner as in the Kootenai of the Philipsburg quadrangle, but they are not so fossiliferous nor so coarse-textured, and the interbedded shales are usually dark gray to blackish, although the olive-green color and gradation to sandstone have been noted.

Other lithologic similarities exist between the so-called Bear River of the Wayan quadrangle and the Kootenai of the Philipsburg quadrangle and other parts of Montana. There are also many differences, among them being the absence of workable coal in the Wayan quadrangle. However, the shales are in some places carbonaceous, and near Auburn, Wyo., a tunnel some 40 feet long has been driven at a coal prospect from which a few lumps of usable coal have been taken.

No recognizable flora has been found in the Wayan "Bear River," but undeterminable stem fragments have been taken from some of the olive-yellow sandstones above the band of

${ }^{3}$ Dowling, D. B., Report on the Cascade coal basin, Alberta, p. 8 , Canada Geol. Survey, 1907.

${ }^{4}$ Calkins, F. C., and Emmons, W. H., Geology and ore deposits of the Philipsburg quadrangle, Mont.: U. S. Geol. Survey Prof. Paper 78, p. 77, 1913.

${ }^{5}$ Idem, pp. 77-79. 
dark shale in the lower part of the formation, and some pieces of dark silicified wood have been found in dark-gray sandstone beds close to the top of the section studied.

From the above descriptions it is clear that the differences between the Wayan "Bear River" and the typical Bear River are so great as to make the correlation of the two formations questionable. On the other hand, the agreement between the beds of the Wayan area and the Kootenai is perhaps not sufficiently close to warrant correlation with that formation until such a correlation is supported by further and more detailed studies. It seems likely that when the detailed stratigraphy of the region north of the Wayan quadrangle, beyond Snake River, is better known the formation will be found to grade upward into the typical Bear River. If the interesting suggestion that the formation should be correlated with the Kootenai of Montana should be substantiated, it might then be possible to determine the stratigraphic relations of the Kootenai and the Bear River.

In the meantime it seems undesirable to apply either term to the formation now called Bear River in the Wayan quadrangle. To avoid ambiguity these beds are named the Wayan formation. The great thickness of the formation, more than 11,800 feet, neither top nor bottom being exposed, and the arrangement of the strata suggest that it may be subdivided later, but this seems inadvisable until detailed studies have been carried farther north. A more detailed description of the formation is given on pages 83-84.

\section{THE FORMATIONS. PREUSS SANDSTONE.}

The Preuss sandstone is named from Preuss Creek, in the northeastern part of the Montpelier quadrangle, about 12 miles northeast of Montpelier. With higher formations it occupies a synclinorium extending northward from the northeastern part of the Montpelier quadrangle completely across the Wayan quadrangle. The eastern extension of the southern part was not traced, but the central and northern parts probably do not extend far east of the area studied.

The formation consists of very fine, evengrained sandstones ranging in color from pale reddish gray to deep dull red. The sandstone is usually calcareous and more or less argillaceous, becoming very shaly in some places. The beds are generally less than 6 inches thick, weather to a dull-red soil, and make the slopes of subordinate ridges. A graphic measurement at the head of Thomas Fork valley gives a thickness of 1,300 feet.

A minor unconformity separates the Preuss sandstone from the underlying Twin Creek limestone.

\section{STUMP SANDSTONE.}

The Stump sandstone is named from Stump Peak, at the head of the north fork of Stump Creek, about the center of T. 6 S., R. 45 E., Boise meridian (unsurveyed). It consists mainly of thin-bedded gray to greenish-gray fine-grained sandstones which weather into platy fragments about an inch thick. Near the base are some beds of compact calcareous sandstone, locally as thick as 6 feet. The grains are very fine and chiefly of colorless quartz. The rock tends to break with a conchoidal fracture and to ring under the hammer. Fresh surfaces have a steel-gray color, but weathered surfaces appear velvety brown. Instead of ledges these beds commonly form lines of irregularly weathered blocks that at first glance resemble trap rock. At the base is a bed of grit, or coarse-grained sandstone, which contains marine fossils of Jurassic age. The component grains are colorless quartz, with some greenish chloritic material, and the cement is calcareous and grayish. The fresh rock has a slight pinkish cast, and weathered surfaces are decidedly pinkish. This is practically the only bed in the entire formation from which fossils were collected, and the collections it yielded at several localities gave practically the same fauna. Fossils identified by T. W. Stanton were Ostrea strigitecula White?, Rhynchonella? sp., Camptonectes? sp., and Pentacrinus sp. A single collection assigned tentatively to the same or nearly the same horizon included Astarte sp., Trigonia sp., and Belemnites sp. According to Mr. Stanton these forms might all be considered as Twin Creek. They are, however, separated from that formation by an unconformity and more than 1,000 feet of unfossiliferous sandstones. 
The Stump sandstone is usually resistant to weathering and forms conspicuous ridges, but south of the Halfway House, on the southern edge of the Wayan quadrangle, it forms a valley. The rock there has probably been weakened by fracturing or other structural disturbance.

The essential features of this formation are present throughout the region studied, but the thickness varies from 200 to 600 feet. Plate XIII, $A$, shows a typical exposure of the Stump sandstone.

\section{GANNETT GROUP}

NAME AND GENERAL FEATURES.

The Gannett group is named from the Gannett Hills, which lie in Bannock County, Idaho, and Lincoln County, Wyo., in the eastern part of the Wayan quadrangle, where all the formations of the group are well exposed. The Gannett Hills have been named in honor of the late Henry Gannett, topographer of the Green River division of the Hayden Survey and subsequently an eminent geographer, who did the first topographic work in this region.

The group includes five distinct subdivisions and has a maximum thickness of over 3,300 feet. It rests, with apparent conformity, upon the Stump sandstone. At the top is the Tygee sandstone, gray and even grained, followed by the Draney limestone, gray and compact. Below are the Bechler and Ephraim conglomerates, separated by the Peterson limestone, which is much like the Draney. Shale appears to be nearly absent from the group.

The fossils thus far collected from the Gannett group are not distinctive, but they are apparently later than Jurassic, so that the age of the group is probably Cretaceous.

The group occurs in much the same areas as the Preuss sandstone, but is confined more to the central portion of the synclinorium.

\section{EPHRAIM CONGLOMERATE.}

The Ephraim conglomerate, at the base of the group, is named from Ephraim Valley, in sec. 36, T. 10 S., R. 45 E., Boise meridian, which lies in the formation. The rock is a red conglomerate with minor amounts of sandstone and some thin bands of gray to purplish limestone. It is about 1,000 feet thick at the type locality, but varies much in thickness and character, be- coming in some regions practically all conglomerate with pebbles, some of which are nearly a foot in diameter. The pebbles represent a wide variety of materials, but perhaps 100 feet above the base there is an olive-yellow band, 25 feet or more thick, in which the pebbles are almost exclusively of dark chert, rounded or subangular, and generally an inch or less in diameter. The Ephraim conglomerate forms most of the mass known as Red Mountain, in the northeastern part of the Montpelier quadrangle, where it is well exposed. (See PI. XIII, B.)

\section{PETERSON LIMESTONE.}

The Peterson limestone is named from Peterson's ranch, along Tygee Creek, in sec. 34, T. 7 S., R. 46 E., Boise meridian, east of which the formation is well exposed. It is about 200 feet thick, massively bedded near the top, and very persistent throughout the region studied, forming prominent ridges that can be followed by the eye for miles from some of the higher summits. (See Pl. XIV, A.) The following fossils from this limestone have been identified by T. W. Stanton: Unio sp., Planorbis (Gyraulus) sp. related to $P$. præcursoris White, Viviparus sp., Goniobasis? sp., and two distinct species of Physa. Fossils of similar types occur in the Kootenai, Bear River, and later formations. The fresh-water gastropods are not distinctive and similar forms of Planorbis are found in both the Morrison and Bear River, but no species of Physa have been reported from beds older than the Bear River.

\section{BECHLER CONGLOMERATE.}

The Bechler conglomerate is named from Bechler Creek, which enters Stump Creek from the north about a quarter of a mile north of the mouth of Boulder Creek, in T. 6 S., R. 45 E., Boise meridian (unsurveyed), in Bannock County. Bechler Creek is named in honor of G. R. Bechler, topographer of the Teton division of the Hayden Survey, who did the first topographic work in the region adjoining the Wayan quadrangle on the north.

The formation is composed of about 1,700 feet of gray, reddish, and "salt and pepper" sandstones with interbedded conglomerates. The "salt and pepper" color predominates, and there is probably over twice as much conglomerate as sandstone. The proportion of 


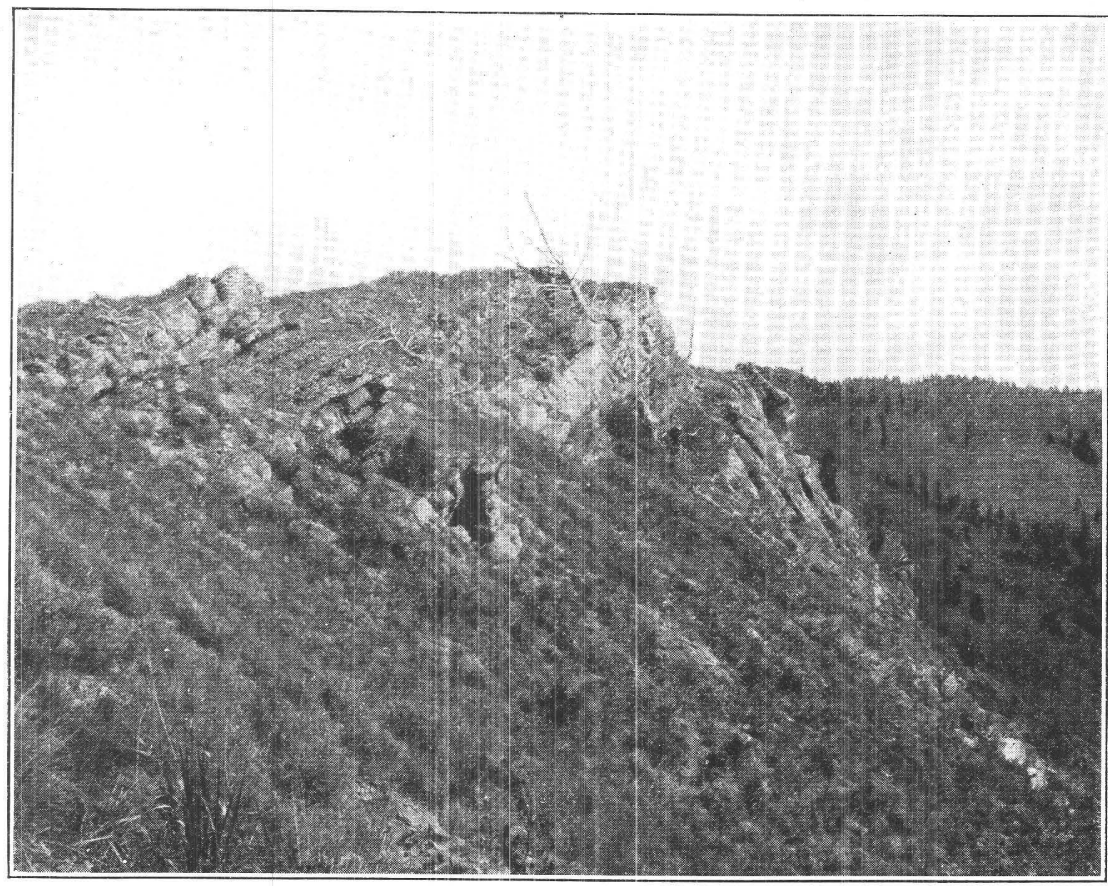

A. VIEW NORTHWEST ALONG THE RIDGE SOUTH OF THE HEAD OF
LANES CREEK, IN THE NORTHWESTERN PART OF THE FREEDOM QUADRANGLE, IDAHO.

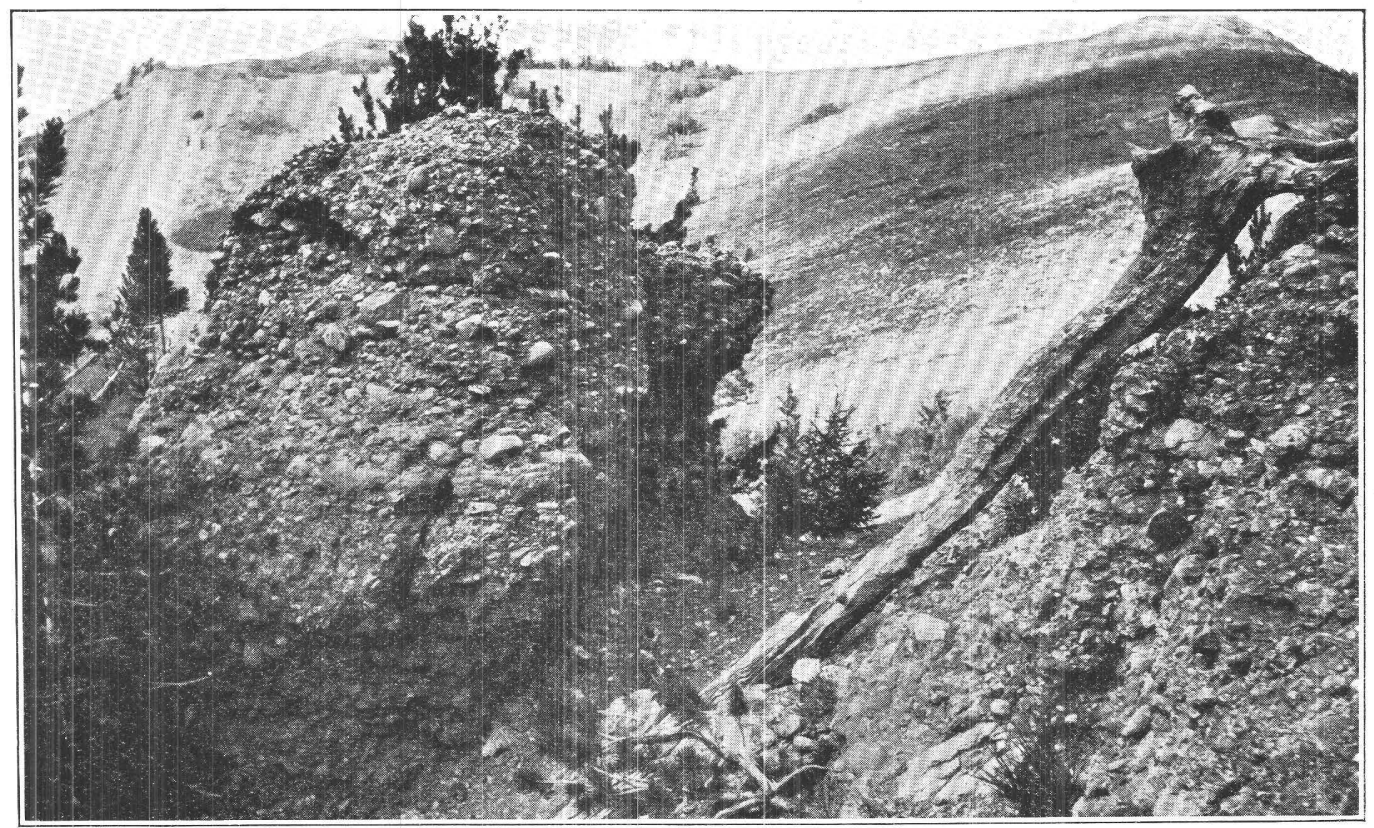

B. VIEW NORTH NEAR THE SUMMIT OF RED MOUNTAIN, IN THE NORTHEASTERN PART OF THE MONTPELIER QUADRANGLE, IDAHO. 


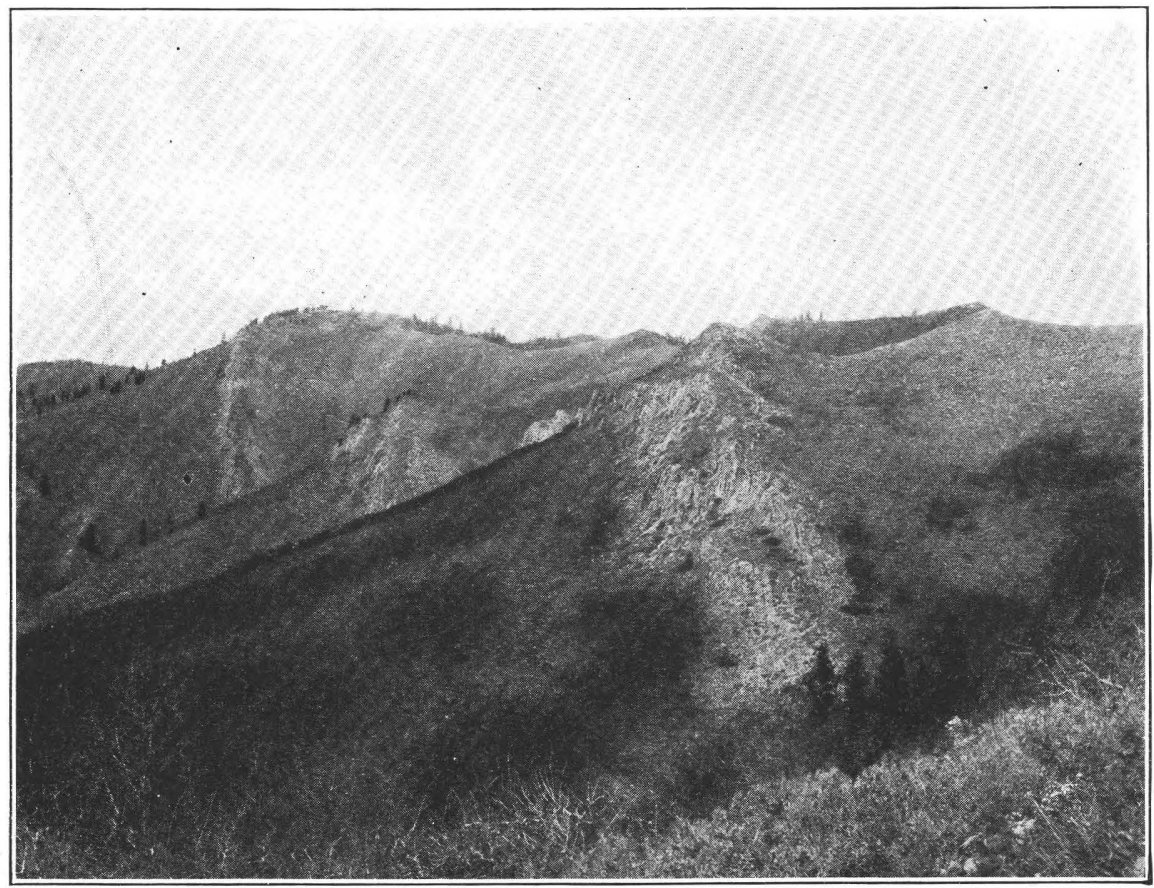

A. VIEW NORTH ALONG THE WEST FLANK OF THE CARIBOU RANGE, IN THE EAST-CENTRAL PART OF THE FREEDOM QUADRANGLE, IDAHO.

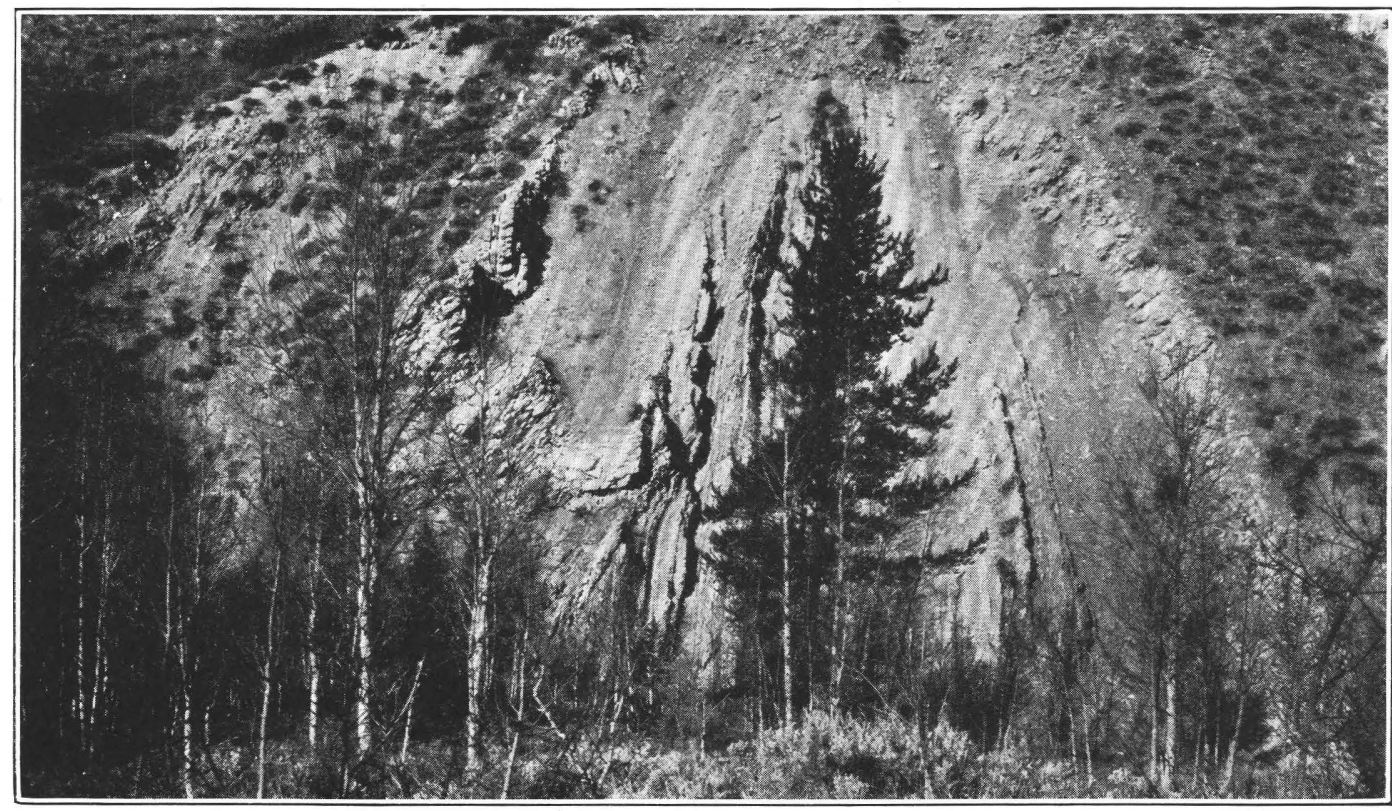

B. SHALY AND LIMY STRATA OF THE LOWER DIVISION OF THE WAYAN FORMATION EXPOSED IN TINCUP CANYON, IN THE NORTH-CENTRAL PART OF THE FREEDOM QUADRANGLE, IDAHO. 
sandstone, however, is greater than in the Ephraim conglomerate. The pebbles in the conglomerate are small, few having a diameter of more than 1 inch.

\section{DRANEY LIMESTONE.}

The Draney limestone is named from the Draney ranch, on Tygee Creek, in sec. 10, T. 8 S., R. 46 E., Boise meridian. The limestone occurs on the top of the ridge about a mile and a quarter east of the ranch. The formation is about 200 feet thick and is fairly massive, the individual beds reaching a maximum thickness of $1 \frac{1}{2}$ feet. The rock is much like that of the Peterson limestone, but is not so massively bedded near the top. It is compact and gray, but weathers to a dirty-white color. The following fossils from this limestone have been identified by T. W. Stanton: Unio sp. related to $U$. vetustus Meek, Viviparus? sp., and Goniobasis? sp., a simple smooth form resembling G:? increbescens Stanton or Amnicola? cretacea Stanton.

\section{TYGEE SANDSTONE.}

The Tygee sandstone is named from Tygee Creek, east of which, in T. 8 S., R. 46 E., the formation is well exposed in association with the Draney limestone on the top of the ridge along the Idaho-Wyoming boundary. The rock is gray to buff, even grained, and without the greenish or reddish tinges of some of the higher sandstones. The top is not exposed, and in much of the region this sandstone with part or all of the limestone below it has been eroded before the deposition of the Wayan formation. At the type locality about 100 feet of this sandstone is exposed.

\section{WAYAN FORMATION.}

Resting unconformably upon the Gannett group is a group of beds composed of sandstones, shales, limestones, and some conglomerates. Neither the top nor the bottom is known, but apparently about 11,800 feet of beds are exposed. These rocks are confined to the northeastern part of the Wayan quadrangle and the region to the north. The formation is named from the settlement of Wayan, in Bannock County, in the northwestern part of the Wayan quadrangle. It occupies the hills immediately east of Wayan and appears to be broadly divisible into two units, the upper composed chiefly of alternating sandstones and shales with some conglomeratic beds, but without significant limestones, and the lower comprising some eight subdivisions, including several thick beds of limestone.

The lower unit in the section exposed in Tincup Canyon includes four sets of red beds, three of limestone and shale, and one of yellow sandstone. These beds in ascending order may be briefly described as follows:

1. Beneath the limestone of the dome that forms a fine arch about a mile west of the mouth of the South Fork of Tincup Creek there is a suggestion of reddish soil that may represent red beds not otherwise exposed.

2. Gray limestones, weathering whitish, with darkcolored shales. The top 20 feet is rather massively bedded limestone; shale and limestone are interbedded below, the proportion of shale gradually increasing toward the base.

3 . Red beds consisting largely of red-weathering soft gray sandstone but including also some gray and red shaly beds and some calcareous beds. These rocks generally form slopes and soil of a light-red color, a brighter color than that of No. 5 .

4. Bands of gray limestone in dark shales. Some of the limestone beds are relatively massive, $1 \frac{1}{2}$ feet or more thick, and project from the weaker shales.

5. Red beds with purplish to reddish-gray sandstone, massive near the top but in thinner beds and associated with shale below, the whole weathering to a red soil and forming fairly smooth slopes.

6. Dark gray to black shale with massive buff limestone near the top and thinner beds of limestone below. (See Pl. XIV, B.)

7. Greenish-gray sandstones and grit, weathering, yellow and reddish, usually forming marked ridges and rough talus slopes of large blocks. The sandstone becomes conglomeratic in places.

8. Red to purplish sandstone with some shaly and some calcareous beds.

Some of these subdivisions may be recognized north and south of Tincup Canyon, but their structure is complex, they appear to vary in lithology and thickness, and they are in places not well expressed topographically. For these reasons it is not yet practicable to map them separately. Their combined thickness is estimated at about 2,800 feet.

The upper unit of the formation, if there is no reduplication by folding and faulting, comprises some 9,000 feet of westward-dipping strata that lie along the upper course of Tincup Creek above the canyon. These beds are chiefly red and gray sandstones, with intervening shales and some calcareous beds. The sandstones form a series of low ridges and points, but the shales are mainly weathered into soil-covered areas. Toward the top yel- 
lowish and brownish sandstones appear, and the uppermost strata recognized are shown only by fragments of dark-gray siliceous sandstone and pieces of dark-brown or black silicified wood weathered white.

The upper unit apparently represents the east limb of a broad syncline, the axial region of which is occupied by the layer containing silicified wood. The syncline is broken on the west by a fault. The northward continuation of the strata and the structural relations suggest that higher beds may appear in that direction.

The fossils collected from the Wayan formation have come almost entirely from the limestone bands. The following forms have been identified by T. W. Stanton: Unio? sp., Rhytophorus? sp., Viviparus? sp., Limnæa?, opercula of gastropods, and fragments of fresh-water shells. An unidentifiable fragment of bone has also been found. In his report on the collections Mr. Stanton remarks:
The collections from the Wayan quadrangle fail to show any characteristic species of the Bear River formation, and if the Bear River is recognized there it must be on some other basis than paleontologic correlation. This is also true of the Beckwith formation, for the reason that in its type area the Beckwith has yielded so few fossils that it can not be said to have a characteristic fauna.

The few fossils found in both the Wayan formation and the Gannett group are poorly preserved fresh-water forms belonging to Unio and to small, uncharacteristic gastropods referred to several genera. There are, therefore, marked faunal similarities between the Gannett group and the Wyan formation, and certain beds in both, particularly the limestones, are also lithologically similar. These likenesses sometimes make difficult the distinction between the formations where the similar beds of each occur in proximity, and thus the unconformity between them, though in many places distinct, is locally hard to detect and probably does not represent any great stratigraphic interval. 